\section{Stabilise immediate loading with intraoral welding}

UK dental dealer Trycare Ltd supplies all intraoral welding components such as the JoiNPlant Intraoral Welder, pliers and bars.

In newly released guidance on the subject, the company said that implant failure can be caused by micromovement through stress exerted on implants during healing.

Primary stability was essential for successful immediate loading and same day surgery, it said, and a technique of splinting abutments directly in the mouth with welded titanium bars provided immediate extra stability.

This procedure eliminated the possibility of errors or distortions in preparing provisional restorations. It increased the likelihood of long-term success of immediate loaded implants.

Peri-implant bone remodels according to forces exerted upon it and optimum distribution of forces on both the implant and the prosthesis was essential for optimal rehabilitation.

Rigid splinting seemed to play an important role in periimplant tissue response, since it was able to reduce the stress on implants.

Additionally, patients desire good retention to relieve the discomfort of mobile dentures, so a quick solution for providing healing stability and good prosthesis retention was intraoral welding. In the mouth, the electrode pliers pincer together the titanium wire and abutment. The electrodes are easy to locate and the pliers hold by themselves, exerting firm pressure on the wire and the abutment.

When activated, the electrical current instantly raises the temperature and fuses the component. Flux is not needed and it only takes milliseconds. A temperature of nearly $1660^{\circ} \mathrm{C}$ is induced but, due to thermal conductivity, all the heat is dissipated without damage to the surrounding tissue.

More information is available by calling 01274885544 or visiting www.trycare.co.uk/adin.
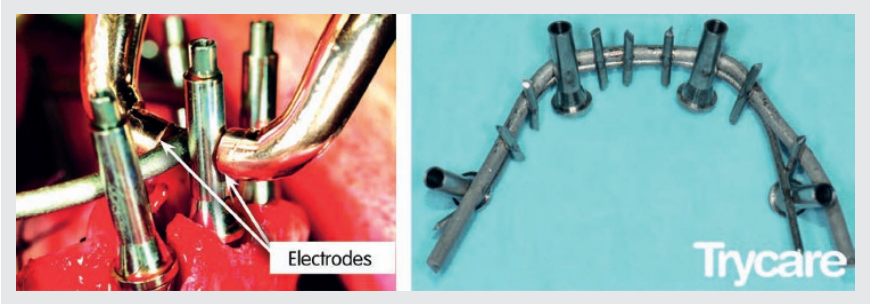

\section{New benefit for ADI members}

The Association of Dental Implantology (ADI) has announced that ADI Clinician members and First Five Years members will be given Premium membership of Dentinal Tubules for free as part of their ADI membership package from December 2018.

Dentinal Tubules offers a huge online content library with top dental educators speaking on the latest clinical techniques, business and core compliance topics.

Online resources including webinars, articles and case studies are available 24/7, making it easy for members to fit studying into a busy schedule and to complete their CPD.

For information on the ADI and to join, visit www.adi.org.uk.

\section{New tabs for long-lasting fresh breath on the go}

Johnson \& Johnson has unveiled its new LISTERINE Go! Tabs to dental health care professionals, ahead of the launch to consumers in the UK.

Chewable LISTERINE Go! Tabs offer an innovative way to get the whole mouth feeling clean and fresh anytime, anywhere, as a handy addition to - not a replacement for - twice-daily mechanical cleaning at home, says the company.

Around $90 \%$ of halitosis is a result of the production of volatile sulphur compounds (VSCs) by oral bacteria, so to tackle this problem, when chewed, for example after a meal, at social gatherings, before a meeting or after a coffee, LISTERINE Go!

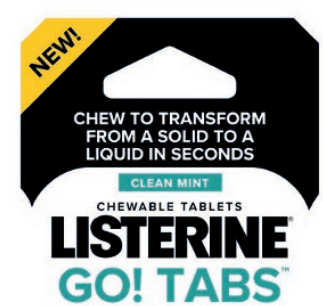

Tabs transform from solid to liquid in seconds, neutralising odours for long-lasting fresh breath.

Johnson \& Johnson's oral care portfolio includes the familiar brand of mouthwash, LISTERINE, with variants suitable for daily use as an integral adjunct to mechanical cleaning to deliver an optimised daily regimen.

In addition, the LISTERINE Advanced Defence range is available to help dental professionals deliver advanced treatment outcomes for patients.

For more information, visit www.listerineprofessional.co.uk.

\title{
Enter the world of magnification
}

To enter the world of magnification, dental professionals are being invited to choose Carl Zeiss loupes available from Nuview.

With these loupes, practitioners can visualise anatomical microstructures, perfect for dentistry where pinpoint clarity is absolutely essential to ensuring optimal outcomes.

There are several models available to suit a variety of clinical needs. These include the EyeMag Pro, EyeMag Smart and GTX, which can be personalised according to each individual's magnification, depth of field and working distance preferences.

To help practitioners find the best fit, the Nuview team works closely with customers to offer advice, assess suitability and take accurate measurements.

More information is available by calling Nuview on 01453 872266, emailing info@nuview-ltd.com, or visiting www.nuview.co or by liking Nuview on Facebook.

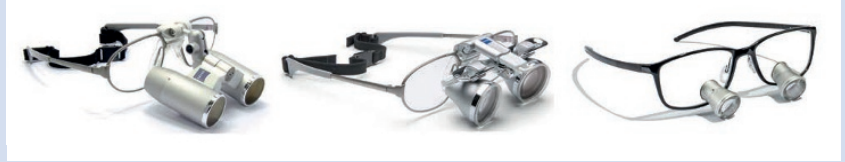

